\title{
Pengaruh Waktu Reaksi Terhadap Yield dan Kandungan Metil Ester Sintesis Biodiesel Ampas Tahu Metode Elektrokatalitik
}

\author{
ELLI PRASTYO, DI AN FARKHATUS S, PUJ I ASTUTI I BRAHI M
}

Akamigas Balongan, Indonesia
Email: elli.prastyo@gmail.com

Received 2020 Desember 2020| Revised 17 Februari 2021 | Accepted 12 Maret 2021

\begin{abstract}
ABSTRAK
Sintesis biodiesel umumnya melalui proses transesterifikasi suhu tinggi menggunakan katalis homogen yang membutuhkan energi cukup besar, pemisahan katalis yang cukup sulit dan terbuang sebagai limbah. Sintesis biodiesel metode elektrokatalitik memberi keuntungan efisiensi lebih daripada transesterifikasi suhu tinggi. Pada penelitian ini, sintesis biodiesel metode elektrokatalitik dilakukan menggunakan elektroda grafit suhu $28^{\circ} \mathrm{C}$ dan tegangan konstan 18,2 Volt. Variabel waktu reaksi selama 60 menit, 120 menit, dan 180 menit, rasio molar minyak - metanol $1: 9$, katalis $\mathrm{BaO} / \mathrm{CaO} 2 \% \mathrm{~b} / \mathrm{b}$ terimpregnasi dengan berat katalis $5 \% \mathrm{~b} / \mathrm{b}$ terhadap minyak digunakan untuk mengevaluasi biodiesel yang dihasilkan. Produk biodiesel berupa metil ester asam lemak bebas dianalisis menggunakan GC-MS. Hasil penelitian menunjukkan yield yang dihasilkan dengan waktu reaksi 60 menit, 120 menit, dan 180 menit berturut turut sebesar $88 \%, 94 \%$, dan 90 dengan waktu reaksi optimum 120 menit. Dan terdapat empat kandungan utama metil ester di semua waktu reaksi yaitu: metil palmiat, metil oleat, metil linoleat, metil stearat. Karakteristik biodiesel yang dihasilkan dilihat dari nilai densitas, viskositas, dan bilangan asam memenuhi kualifikasi SNI Biodiesel 04-7182-2006.
\end{abstract}

Kata kunci: biodiesel, ampas tahu, elektrokatalitik, yield, metil ester

\begin{abstract}
Synthesis of biodiesel generally uses a transesterification process at high temperature with homogeneous catalyst that requires a large amount of energy, separation of the catalyst is quite, and is wasted as waste. Electrocatalytic biodiesel synthesis method gives more advantages in high temperature transesterification. The reaction time variables were 60 minutes, 120 minutes, and 180 minutes, the oil-methanol molar ratio was 1: 9, the $\mathrm{BaO} / \mathrm{CaO} 2 \% \mathrm{w} / \mathrm{w}$ catalyst was impregnated with a catalyst weight of $5 \% \mathrm{w} / \mathrm{w}$ to the oil used for the resulting biodiesel. The results showed that the results with a reaction time of 60 minutes, 120 minutes, and 180 minutes were $88 \%, 94 \%$, and 90 minutes respectively with an optimal reaction time of 120 minutes. It showed that there were four main ingredients of methyl ester at all reaction times, namely: methyl palmyate, methyl oleate, methyl linoleate, methyl stearate. The characteristics of the resulting biodiesel seen from the density, viscosity, and acid number have met the SNI Biodiesel 04-7182-2006 qualifications.
\end{abstract}

Keywords: biodiesel, tofu waster, electrocatalytic, yield, methyl ester

J urnal Tekno Insentif - 54 
Pengaruh Waktu Reaksi Terhadap Yield dan Kandungan Metil Ester Sintesis Biodiesel Ampas Tahu Metode Elektrokatalitik

\section{PENDAHULUAN}

Bahan bakar minyak yang mengalami peningkatan kebutuhan di berbagai sektor kehidupan berdampak terhadap proses distribusi dan pemenuhan kebutuhan pasar. Sektor transportasi merupakan salah satu yang mengalami dampak secara langsung. Direktorat Jenderal Energi Baru Terbarukan dan Konservasi Energi Kementerian ESDM menyatakan bahwa beberapa tahun terakhir pertumbuhan konsumsi energi Indonesia mencapai $7 \%$ per tahun. Nilai konsumsi energi Indonesia lebih tinggi dibandingkan pertumbuhan konsumsi energi dunia yaitu sebesar 2,6\% per tahun (Anwaristiawan, dkk, 2018). Indonesia adalah negara yang memiliki sumber daya hayati dan berpotensi tinggi untuk diolah menjadi sumber energi alternatif. Minyak nabati merupakan salah satu bahan baku energi alternatif yang berasal dari sumber daya hayati dan dapat digunakan dalam pembuatan biodiesel. Biodiesel merupakan energi alternatif yang diproduksi dari minyak nabati atau lemak hewan dengan bantuan katalis yang bersifat asam atau basa dengan reaksi transesterifikasi.

Kedelai merupakan salah satu bahan pokok pangan yang selalu mengalami peningkatan permintaan setiap tahun. Kedelai dapat diproses menjadi beberapa produk diversifikasi pangan, salah satunya adalah tahu. Proses produksi tahu menggunakan bahan baku kedelai menghasilkan produk samping salah satunya adalah ampas tahu yang belum dimanfaatkan secara maksimal sebagai sumber energi alternatif. Lemak dan protein merupakan beberapa komponen organik yang terdapat pada ampas tahu. Komposisi lemak dalam ampas tahu dapat diekstrak untuk mendapatkan minyak ampas tahu untuk dimanfaatkan lebih lanjut sebagai bahan baku biodiesel (Buchori, 2012).

Reaksi transesterifikasi merupakan salah satu tahapan dalam proses sintesis biodiesel yang dilakukan dengan menggunakan katalis asam atau katalis basa homogen seperti $\mathrm{NaOH}, \mathrm{KOH}$ dan $\mathrm{H}_{2} \mathrm{SO}_{4}$. Reaksi transesterifikasi menggunakan katalis homogen membutuhkan suhu yang relatif tinggi agar berjalan cepat dan efisien. Sintesis biodiesel menggunakan katalis homogen memiliki beberapa kekurangan, salah satunya adalah proses pemisahan antara biodiesel dan katalis yang digunakan sehingga kurang efisien. Bahan baku dalam sintesis biodiesel dengan nilai asam lemak bebas dan kandungan air tinggi berpotensi menimbulkan permasalahan jika dalam proses sintesis biodiesel menggunakan katalis basa homogen. Permasalahan yang biasanya muncul adalah terjadinya reaksi penyabunan, meningkatkan viskositas biodiesel, dan berkurangnya yield biodiesel. Penggunaan katalis heterogen merupakan salah satu alternatif untuk mengatasi masalah yang terjadi pada penggunaan katalis homogen (Muhriz dkk, 2011).

Dibandingkan katalis homogen, katalis heterogen memiliki berbagai keunggulan antara lain memiliki situs aktif dan system penyangga, dapat dilakukan modifikasi katalis, kemudahan pemisahan katalis dari produk, sifat mampu recycle. $\mathrm{CaO}$ merupakan salah satu material yang dapat dimanfaatkan menjadi katalis pada proses sintesis biodiesel. CaO memiliki situs aktif dan aktivitas katalistik tinggi, biaya murah, tahan lama, serta kekuatan basa yang tinggi. Katalis heterogen dapat dilakukan proses modifikasi dengan tujuan meningkatkan kemampuan katalis dengan proses impregnasi. Impregnasi katalis dilakukan melalui metode basah dengan $\mathrm{BaO}$ sebagai penyangga pada katalis $\mathrm{CaO}$. Barrium oksida merupakan oksida logam yang sangat aktif dan akan larut dalam media reaksi. Katalis $\mathrm{BaO}$ stabil bahkan setelah 10 siklus reaksi dan dapat mempercepat banyak reaksi kimia (Wisnu dkk, 2017). Katalis yang diperoleh kemudian digunakan untuk proses sintesis biodiesel secara elektrokatalitik.

Sintesis biodiesel dengan metode elektrolisis merupakan metode yang sangat memberi keuntungan. Metode elektrolisis memanfaatkan aliran listrik dapat menciptakan efek katalistik yang bersifat asam dan basa, sehingga terjadi fenomena elektrolisis air pada anoda dan katoda

J urnal Tekno Insentif - 55 
dimana air mengalami peruraian molekul menjadi ion $\mathrm{H}+$ dan $\mathrm{OH}$ - pada suhu ruang $( \pm 30$ ${ }^{\circ} \mathrm{C}$ ). I on $\mathrm{H}+$ dan $\mathrm{OH}$ - yang terbentuk pada permukaan elektroda akan dimanfaatkan sebagai katalis asam maupun basa dalam sistem untuk membantu kedua proses reaksi yang berjalan dalam satu waktu (Putra dkk, 2015; Allioux dkk, 2017).

Pada penelitian yang lain, diketahui penggunaan katalis tambahan pada proses elektrosintesis biodiesel dapat meningkatkan tingkat rendemen \%FAME. Katalis homogen seperti $\mathrm{KOH}$ mendapatkan tingkat konversi biodiesel mencapai lebih dari $90 \%$ (Fereidooni dkk, 2017). Konversi biodiesel lebih dari $94 \%$ dapat dicapai menggunakan katalis heterogen bersifat basa seperti chitosan dan atau $\mathrm{CaO}$ dari cangkang telur. Konversi biodiesel dapat ditingkatkan dengan menentukan waktu reaksi yang tepat pada sintesis biodiesel. Waktu reaksi yang tepat dapat meningkatkan efisiensi penggunaan energi dalam sintesis biodiesel, hal ini karena reaksi dalam sintesis biodiesel bersifat reversible.

Ampas tahu digunakan pada penelitian kali ini untuk proses sintesis biodiesel menggunakan metode elektrolisis. Katalis $\mathrm{CaO} / \mathrm{BaO}$ ter impregnasi dengan konsentrasi 5\% digunakan berdasarkan variabel waktu reaksi. Produk biodiesel dibandingkan dengan standar biodiesel yang telah diatur oleh SNI ditunjukkan pada Tabel 1.

Tabel 1. Karakteristik Biodiesel SNI

\begin{tabular}{|c|l|c|c|}
\hline No & \multicolumn{1}{|c|}{ Karakteristik } & Satuan & Nilai \\
\hline 1 & Densitas $15^{\circ} \mathrm{C}$ & $\mathrm{kg} / \mathrm{m} 3$ & $850-890$ \\
\hline 2 & Viskositas kinematik $40^{\circ} \mathrm{C}$ & $\mathrm{cSt}$ & $2.3-6.0$ \\
\hline 3 & Angka setana & & $\mathrm{min} .51$ \\
\hline 4 & Titik nyala & ${ }^{\circ} \mathrm{C}$ & $\mathrm{min} .100$ \\
\hline 5 & Titik kabut & ${ }^{\circ} \mathrm{C}$ & maks. 18 \\
\hline 6 & Kandungan air & $\%$ vol & maks. 0.05 \\
\hline 7 & Gliserol bebas & $\% \mathrm{massa}$ & maks. 0.02 \\
\hline 8 & Angka asam & $\mathrm{mg}$-KOH $/ \mathrm{g}$ & maks. 0.5 \\
\hline 9 & Kadar alkil ester & $\% \mathrm{massa}$ & min. 96.5 \\
\hline
\end{tabular}

\section{METODE PENELITIAN}

\subsection{Alat dan Bahan}

Peralatan yang digunakan pada penelitian ini: set alat ekstraktor soxhlet, set alat destilasi, corong pisah, buret, piknometer, viskosimeter Ostwald, furnace, oven, magnetic stirrer, alat alat gelas lab, power supply $220 \mathrm{~V}$ dengan output 0 - $30 \mathrm{~V}$ adjustable. Rancangan reaktor elektrokatalitik biodiesel yang digunakan dalam penelitian ditunjukkan pada Gambar 1.

Bahan yang digunakan pada penelitian ini: minyak ampas tahu, benzene, metanol, etanol, cosolvent Tetra Hidro Furan (THF), $\mathrm{NaOH}, \mathrm{Ba}\left(\mathrm{NO}_{3}\right)_{2}, \mathrm{CaO}$, elektroda grafit dengan diameter 10 $\mathrm{mm}$ dan panjang $130 \mathrm{~mm}$, dan aquades.

\subsection{I mpregnasi Katalis}

Impregnasi katalis dilakukan dengan memasukkan serbuk $\mathrm{CaO}$ ke dalam larutan $\mathrm{Ba}\left(\mathrm{NO}_{3}\right)_{2}$. Larutan dipanaskan suhu $60-70^{\circ} \mathrm{C}$ sambil diaduk sampai terbentuk slury. Slury $\mathrm{CaO} / \mathrm{BaO}$ selanjutnya dihilangkan kada air menggunakan oven pada suhu $100^{\circ} \mathrm{C}$ selama 3 jam. Setelah kering, $\mathrm{CaO} / \mathrm{BaO}$ kemudian di kalsinasi menggunakan furnace pada suhu $550^{\circ} \mathrm{C}$ selama 4 jam. $\mathrm{CaO} / \mathrm{BaO}$ dengan konsentrasi $\mathrm{BaO} 2 \% \mathrm{~b} / \mathrm{b}$ kemudian digunakan pada aplikasi proses sintesis biodiesel. 


\subsection{Ekstraksi Minyak Ampas Tahu}

1. Ampas tahu diperas menggunakan kain blacu untuk mengurangi kadar air tahap awal.

2. Ampas tahu kemudian dioven suhu $110^{\circ} \mathrm{C}$ selama 5 jam untuk mengurangi kadar air.

3. Ampas tahu kering diekstraksi menggunakan pelarut benzene selama 3-4 jam dengan perbandingan pelarut : ampas tahu adalah 5:1 (b/v).

4. Campuran solvent dengan minyak ampas tahu dipisahkan dengan proses destilasi

5. Minyak ampas tahu yang diperoleh dianalisis nilai Free Fatty Acid (FFA).

\subsection{Sintesis Biodiesel Elektrokatalitik}

Methanol digunakan sebagai reaktan dengan perbandingan rasio molar methanol:minyak adalah 9:1. Volume Minyak ampas tahu yang digunakan $50 \mathrm{~mL}$ dengan volume methanol 19,14 $\mathrm{mL}$. Co - Solvent digunakan berupa Tetra Hidro Furan (THF) untuk menyatukan lapisan methanol dan minyak ampas tahu dengan perbandingan methanol dan THF yaitu 1:1 v/v. Reaktor elektrokatalitik diisi dengan campuran metanol, minyak ampas tahu, THF, dan katalis $\mathrm{CaO} / \mathrm{BaO} 2 \% \mathrm{~b} / \mathrm{b}$. Reaktor elektrolisis dilengkapi 2 buah elektroda grafit dengan dimensi 10 $\mathrm{mm}$ (diameter) dan $130 \mathrm{~mm}$ (panjang). Proses sintesis biodiesel dilakukan pada suhu ruangan $\left(28^{\circ} \mathrm{C}\right.$ ) dengan tegangan konstan 18,2 Volt dan dengan pengadukan.

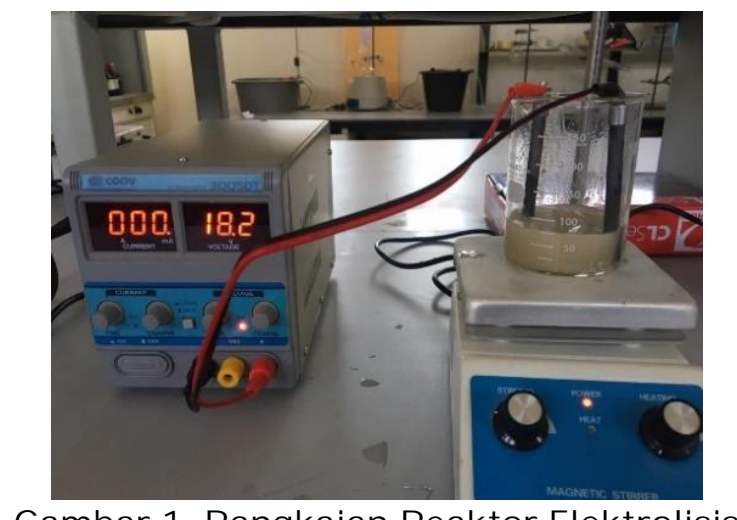

Gambar 1. Rangkaian Reaktor Elektrolisis

\subsection{Analisis Asam Lemak Bebas}

Minyak ampas tahu dengan berat $20 \mathrm{~g}$ dimasukkan dalam Erlenmeyer $250 \mathrm{~mL}$ yang sudah berisi $50 \mathrm{~mL}$ etanol $95 \%$. Larutan dipanaskan sampai mendidih menggunakan hot plate kemudian didinginkan hingga mencapai temperatur ruangan. Larutan yang telah dingin kemudian ditambahkan indicator fenolftalein untuk dilakukan titrasi menggunakan $\mathrm{KOH} 0,1 \mathrm{~N}$ sampai titik ekuivalen.

\subsection{Analisis Gas Chromatografy Mass Spectrometry (GC-MS)}

Analisis GC-MS digunakan untuk mengidentifikasi komponen yang terdapat pada produk biodiesel baik secara kualitatif maupun kuantitatif. Analisis GC-MS dilakukan di laboratorium Fakultas Pendidikan MIPA Universitas Pendidikan Indonesia (UPI).

\section{HASI L DAN PEMBAHASAN}

\subsection{Karakteristik Minyak Ampas Tahu}

Minyak kedelai ampas tahu diperoleh melalui ekstraksi sokhlet dengan pelarut organik (benzene) dengan 15 kali siklus. Ekstraksi ampas tahu bertujuan untuk mengambil kandungan organik khususnya lemak dengan pelarut benzene. Minyak ampas tahu yang diperoleh sebelum digunakan sebagai bahan baku sintesis biodiesel dilakukan analisis free fatty acid (FFA), density, dan viscosity yang disajikan pada Tabel 2. 
Tabel 2. Hasil Analisis Minyak Ampas Tahu

\begin{tabular}{|c|c|c|}
\hline Keterangan & Nilai & Satuan \\
\hline FFA & 0,6 & $\%$ \\
\hline Densitas & 0,92 & $\mathrm{gr} / \mathrm{mL}$ \\
\hline Viskositas & 0,07 & poise \\
\hline
\end{tabular}

Nilai FFA minyak ampas tahu yang dihasilkan sebesar 0,6 \% sehingga syarat untuk digunakan sebagai bahan baku pembuatan biodiesel sudah dipenuhi. Nilai FFA minyak diatas $1 \%$ tidak disarankan menggunakan katalis basa secara langsung tanpa melalui proses esterifikasi. Nilai FFA yang tinggi dapat menurunkan rendemen biodiesel, meningkatkan bilangan penyabunan, dan meningkatkan viskositas biodiesel (Buchori, 2012). Nilai FFA yang tinggi berkorelasi dengan nilai densitas minyak ampas tahu yang dihasilkan dimana semakin tinggi FFA semakin tinggi pula nilai densitas yang dihasilkan.

Nilai densitas minyak ampas tahu yang dihasilkan sebesar 0,92 memiliki nilai yang sama dengan minyak kedelai standar SNI dengan rentang 0,916 - 0,922 gr/mL (Buchori, 2012). Jumlah siklus yang tinggi dan pemakaian solvent benzene konsentrasi $96 \%$ dalam proses ekstraksi menyebabkan lemak yang terekstrak semakin tinggi karena nilai dipol benzene sama dengan momen dipol minyak. Konsentrasi pelarut yang digunakan dan waktu siklus mempengaruhi nilai densitas biodiesel yang dihasilkan, semakin tinggi konsentrasi pelarut yang digunakan densitas minyak yang dihasilkan semakin tinggi (Irawati, 2018). Nilai densitas selalu berkorelasi dengan nilai viskositas, dimana semakin tinggi densitas, maka semakin tinggi pula viskositas.

\subsection{Pengaruh Variasi Waktu Terhadap Yield Biodiesel}

Sintesis biodiesel dilakukan menggunakan metode elektrokatalitik melalui reaksi transesterifikasi. Reaksi transesterifikasi dilakukan pada suhu kamar menggunakan katalis $\mathrm{BaO} / \mathrm{CaO}$ terimpregnasi $2 \% \mathrm{~b} / \mathrm{b}$. Variabel tidak tetap dalam penelitian adalah waktu reaksi (60, 120, 180 menit). Hasil reaksi transesterifikasi terbentuk 3 lapisan dari bawah ke atas yaitu katalis, gliserol, dan biodiesel. Katalis $\mathrm{BaO} / \mathrm{CaO}$ heterogen mudah dipisahkan dari biodiesel dan gliserol yang terbentuk. Gliserol dan biodiesel yang terbentuk dipisahkan menggunakan corong pisah yang didiamkan selama 24 jam. Biodiesel yang diperoleh dievaporasi suhu $85^{\circ} \mathrm{C}$ untuk menghilangkan sisa methanol dan THF. Biodiesel yang diperoleh berwarna kuning keemasan kemudian dihitung yield untuk masing-masing variable yang disajikan pada Tabel 3.

Tabel 3. Nilai Yield Biodiesel

\begin{tabular}{|c|c|c|c|c|}
\hline Waktu Reaksi & Yield (\%) & $\begin{array}{c}\text { Densitas } \\
\text { (g/ } \mathbf{~ m L})\end{array}$ & $\begin{array}{c}\text { Viscositas kinematik } \\
\text { (cSt) }\end{array}$ & $\begin{array}{c}\text { Angka Asam } \\
\text { (mg-KOH/ g-biodiesel }\end{array}$ \\
\hline 60 menit & 88 & 0,864 & 5,22 & 0,22 \\
\hline 120 menit & 94 & 0,866 & 5,35 & 0,25 \\
\hline 180 menit & 90 & 0,885 & 5,65 & 0,18 \\
\hline
\end{tabular}




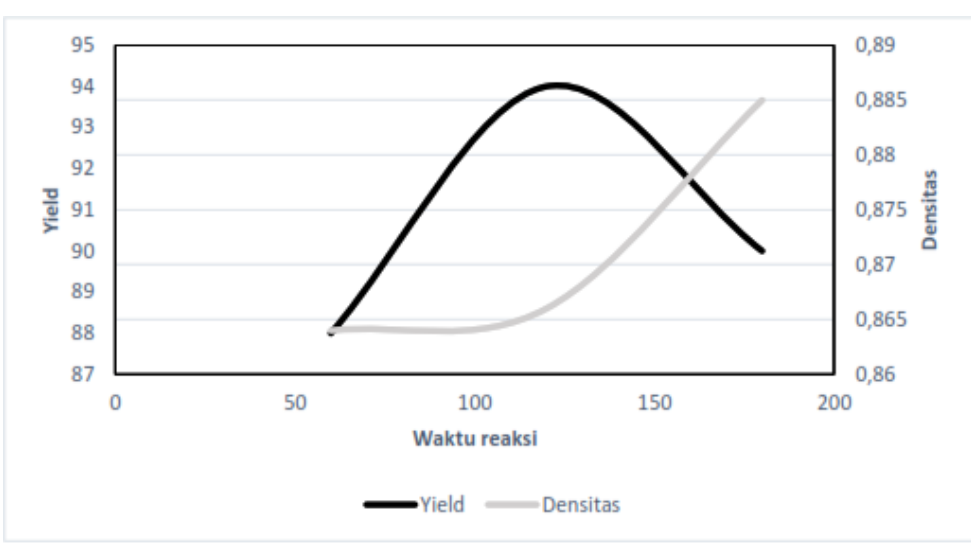

\section{Gambar 2. Trend Yield Terhadap Waktu Reaksi dan Densitas}

Gambar 2 dan tabel 3 menunjukkan jika waktu reaksi mempengaruhi nilai yield biodiesel yang dihasilkan. Nilai tertinggi sebesar 95\% diperoleh pada waktu reaksi 120 menit dengan konsentrasi katalis $5 \% \mathrm{~b} / \mathrm{b}$. Nilai yield terendah sebesar $88 \%$ diperoleh ketika biodiesel direaksikan selama 60 menit. Waktu reaksi yang semakin tinggi berimplikasi terhadap kontak antara situs aktif katalis, methanol, dan bahan baku semakin lama, sehingga mengakibatkan konversi biodiesel meningkat. Reaksi biodiesel merupakan reaksi reversible sehingga ketika kesetimbangan telah tercapai sebaiknya proses sintesis dihentikan agar energi yang digunakan efisien (Dedy, 2019). Hal ini dapat dibuktikan ketika reaksi dilanjutkan sampai 180 menit, konversi biodiesel menurun dibandingkan waktu reaksi 120 menit. Nilai konversi yang tinggi merupakan salah satu dampak dari penggunaan katalis heterogen termodifikasi $\mathrm{BaO} / \mathrm{CaO}$ yang bersifat basa. Aktivitas katalis semakin meningkat seiring dengan meningkatnya tingkat kebasaan katalis yang digunakan. Sifat basa dari katalis meningkatkan situs aktif sehingga nilai keelektronegatifan kation logam terkonjugasi meningkat. Gaya atraktif elektron kation logam terkonjugasi dan sifat basa anion oksigen meningkat karena nilai keelektronegatifan kation logam terkonjugasi (Chen, dkk, 2012).

Komposisi asam lemak pada bahan baku sintesis biodiesel berkorelasi terhadap nilai densitas yang dihasilkan. Gambar 2 menunjukkan hubungan antara nilai densitas terhadap yield dan waktu reaksi. Nilai densitas biodiesel yang dihasilkan berbanding terbalik dengan nilai yield terhadap waktu reaksi. Hal ini karena adanya reaksi transesterfikasi yang mengkonversi bahan baku dengan kandungan asam lemak dan trigliserida menjadi metil ester. Panjang rantai karbon dan semakin banyak jumlah ikatan rangkap akan meningkatkan nilai densitas biodiesel. Nilai konversi yang tinggi menyebabkan hasil samping berupa gliserol dan air akan semakin kecil terbentuk sehingga nilai densitas semakin menurun (Pahlevi, dkk, 2015).

Nilai densitas selalu berkorelasi dengan nilai viskositas dari zat tersebut. Viskositas kinematic biodiesel minyak ampas tahu sebesar 5,4 cSt, hasil ini sudah sesuai standart SNI. Komposisi asam lemak dan tingkat kemurnian berkaitan dengan nilai viskositas biodiesel. Hasil analisis viskositas biodiesel yang dihasilkan menunjukkan bahwa semakin lama waktu reaksi berimplikasi terhadap meningkatnya nilai viskositas yang dihasilkan. Nilai viskositas berkorelasi dengan kompnen penyusun dari biodiesel yang dapat ditunjukkan melalui analisis GC-MS. Biodiesel mengandung multi senyawa organic hasil dari reaksi transesterifikasi seperti mono, di, dan ikatan rantai siklik (BSEN, 14105:2003). Hasil ini didukung oleh data GC-MS yang ditampilkan pada gambar 2, gambar 3, dan gambar 4. Karakteristik biodiesel yang dihasilkan ditinjau dari nilai densitas, viskositas, dan bilangan asam sudah memenuhi standart yang ditetapkan. 


\subsection{Penentuan Kandungan Metil Ester Biodiesel}

Biodiesel hasil metode elektrokatalitik dengan reaksi transesterifikasi katalis basa $\mathrm{BaO} / \mathrm{CaO}$ kemudian dilakukan analisis GC-MS. Analisis GC-MS digunakan untuk mengidentifikasi kandungan metil ester pada biodiesel yang dihasilkan baik secara kualitatif maupun kuantitatif. Puncak-puncak metil ester dan senyawa lain yang terkandung pada biodiesel ditunjukkan dengan data berupa kromatogram hasil analisis GC, berat molekul dan struktur molekul pada tiap puncak dan fragmentasi dari molekul yang terdeteksi ditunjukkan dari analisis MS. Senyawa ester dengan rantai karbon pendek terlebih dahulu terdeteksi kemudian diikuti dengan rantai karbon yang lebih panjang. Penyebaran cuplikan di antara dua fase merupakan dasar pemisahan secara kromatografi gas. Hasil analisis menggunakan GC-MS ditunjukkan pada Gambar berikut.

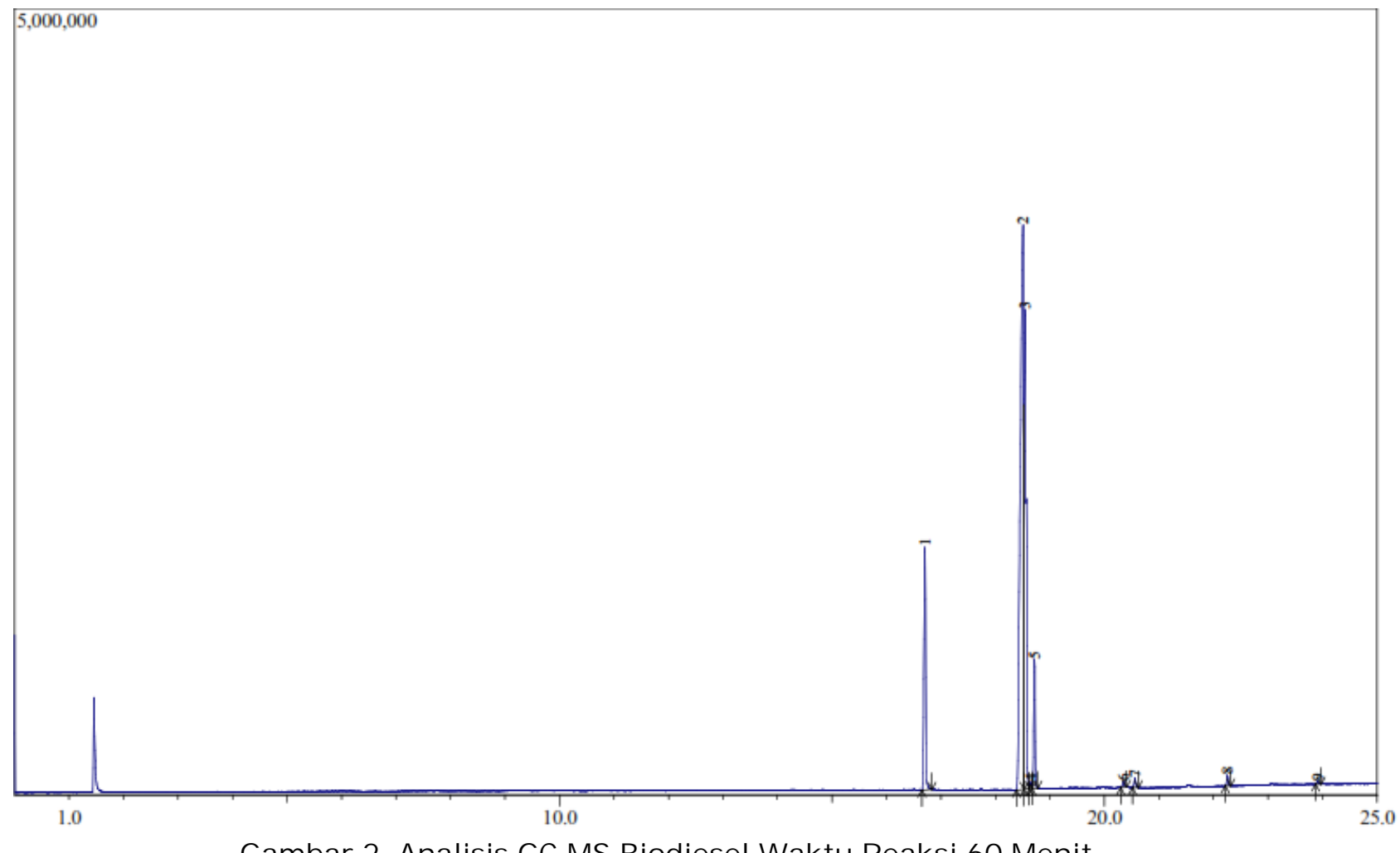

Gambar 2. Analisis GC MS Biodiesel Waktu Reaksi 60 Menit 
Pengaruh Waktu Reaksi Terhadap Yield dan Kandungan Metil Ester Sintesis Biodiesel Ampas Tahu Metode Elektrokatalitik

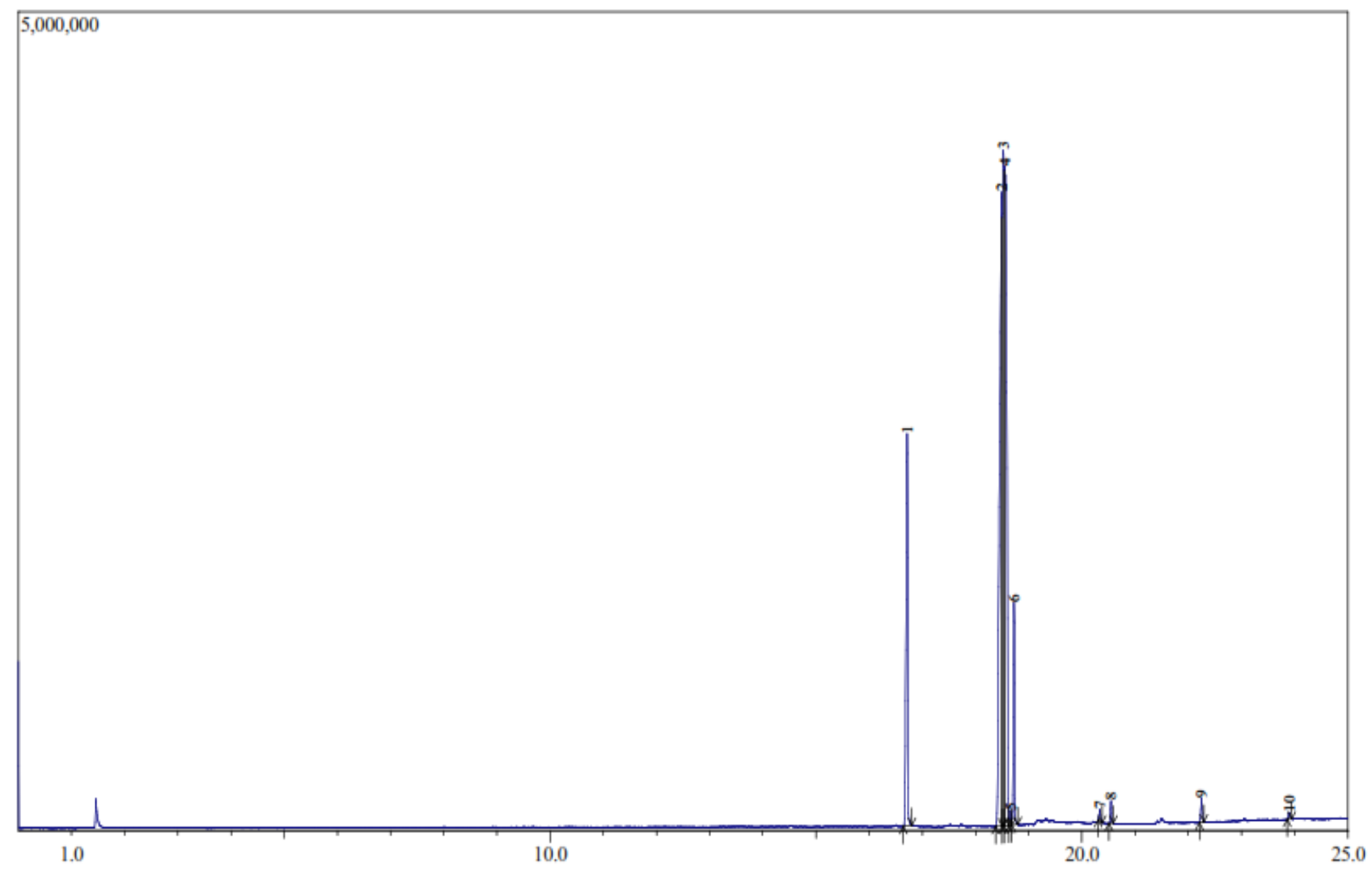

Gambar 3. Analisis GC MS Biodiesel Waktu Reaksi 120 Menit

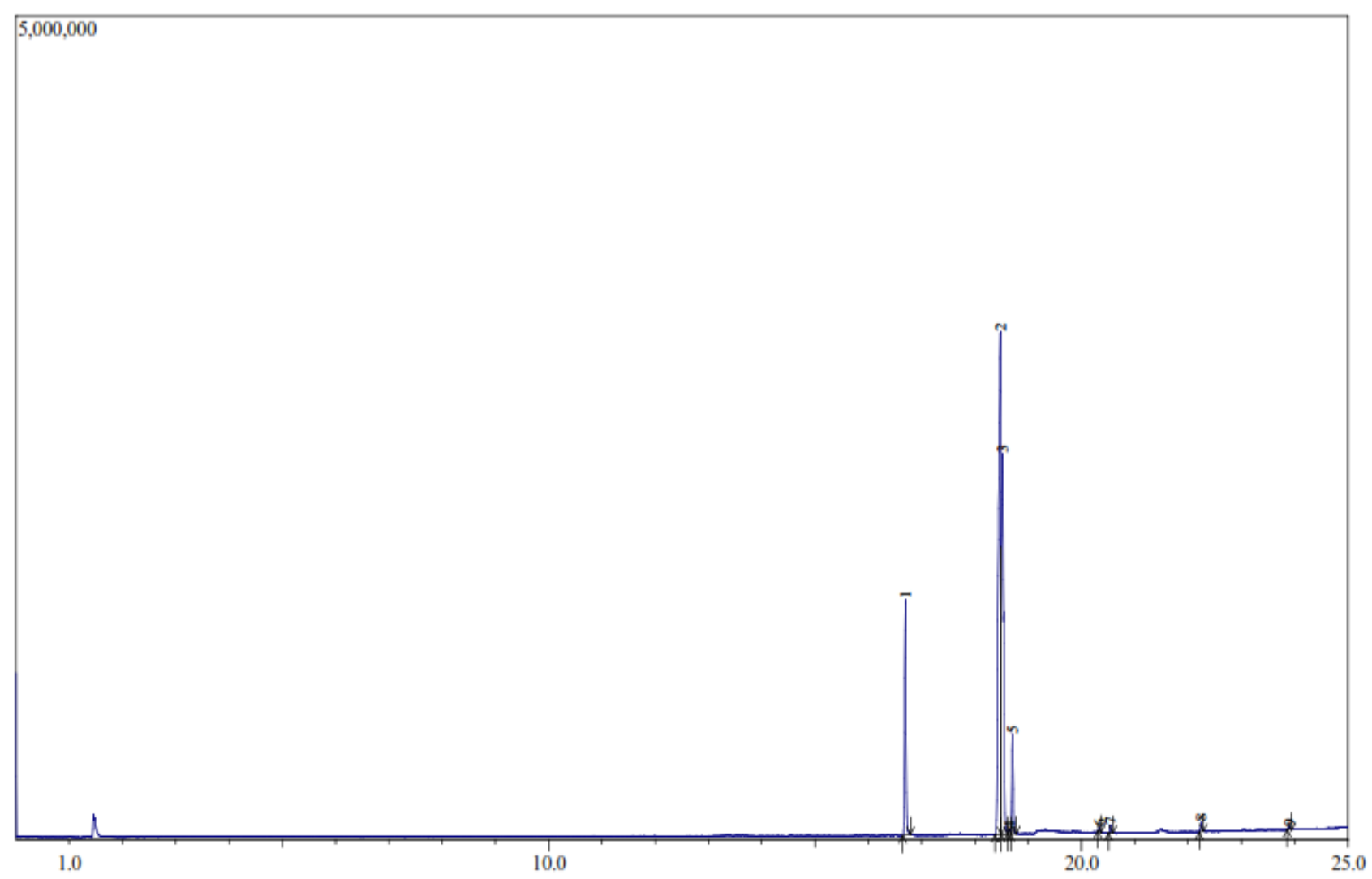

Gambar 4. Analisis GC MS Biodiesel Waktu Reaksi 180 Menit 
Tabel 4. Perbandingan Komposisi Metil Ester Biodiesel

\begin{tabular}{|c|c|c|c|c|c|c|}
\hline \multirow{2}{*}{ Senyawa } & \multicolumn{6}{|c|}{ Waktu Reaksi } \\
\cline { 2 - 7 } & \multicolumn{2}{|c|}{$\mathbf{0}$} & \multicolumn{2}{c|}{$\mathbf{1 2 0}$} & \multicolumn{2}{c|}{$\mathbf{1 8 0}$} \\
\cline { 2 - 7 } & \% Area & Peak & \% Area & Peak & \% Area & Height \\
\hline Metil Palmiat & 11,48 & 1 & 12,35 & 1 & 12,59 & 1 \\
\hline Metil Linoleat & 55,56 & 2 & 30,32 & 2 & 50,41 & 2 \\
\hline Metil Oleat & 26,29 & 3 & 30,33 & 3 & 30,47 & 3 \\
\hline $\begin{array}{c}\text { Metil Oktadeka 9,12 } \\
\text { Dienoat }\end{array}$ & - & - & 19,56 & 4 & - & - \\
\hline $\begin{array}{c}\text { Metil 9,12,15 } \\
\text { Oktadekatrinoat }\end{array}$ & 0,31 & 4 & 0,41 & 5 & 0,33 & 4 \\
\hline Metil Stearat & 4,93 & 5 & 5,40 & 6 & 4,91 & 5 \\
\hline $\begin{array}{c}\text { Metil } \\
\text { Siklopropanoktanoat }\end{array}$ & - & - & - & - & 0,21 & 6 \\
\hline Metil 11 Eicosanoat & 0,33 & 6 & 0,27 & 7 & 0,43 & 7 \\
\hline Metil Arachidic & 0,45 & 7 & 0,54 & 8 & - & - \\
\hline Metil Behenat & 0,49 & 8 & 0,61 & 9 & 0,49 & 8 \\
\hline Metil Lignoserat & 0,16 & 9 & 0,20 & 10 & 0,17 & 9 \\
\hline
\end{tabular}

Hasil analisis GC MS menyatakan bahwa terdapat kandungan senyawa metil ester dalam sintesis biodiesel. Hasil analisis GC MS berupa kromatogram menunjukkan adanya 9 puncak untuk waktu reaksi 60 menit, 10 puncak waktu reaksi 120 menit, 9 puncak waktu reaksi 180 menit. Hasil analisis GC-MS menunjukkan puncak terbanyak diperoleh pada waktu reaksi 120 menit. Hal ini berkorelasi dengan nilai yield yang dihasilkan dengan nilai tertinggi terdapat pada waktu reaksi 120 menit. Puncak yang terdeteksi pada analisis GC-MS menunjukkan jenis senyawa metil ester yang terdapat pada biodiesel. Hasil analisis GC-MS menunjukkan terdapat empat puncak dengan nilai tertinggi pada semua waktu reaksi, yaitu metil palmiat, metil oleat, metil linoleate, dan metil stearat. Metil palmiat sebagai komponen utama pembentuk biodiesel minyak ampas tahu mempunyai rumus molekul $\mathrm{C}_{17} \mathrm{H}_{34} \mathrm{O}_{2}$, Metil Oleat $\mathrm{C}_{19} \mathrm{H}_{36} \mathrm{O}_{2}$, Metil linoleate $\mathrm{C}_{19} \mathrm{H}_{34} \mathrm{O}_{2}$, dan metil stearat $\mathrm{C}_{19} \mathrm{H}_{38} \mathrm{O}_{2}$ (Arita dkk, 2013).

Biodiesel memiliki syarat salah satunya adalah nilai bilangan setana yang dihasilkan. Nilai bilangan setana yang tinggi dapat dicapai ketika biodiesel memiliki senyawa atom $\mathrm{C}$ sebanyak 16 atau lebih (Kayser, 2014). Empat jenis metil ester nilai tertinggi dengan atom C lebih dari 16 yaitu, metil palmitat, metil linoleat, metil oleat, dan metil stearate terdapat pada biodiesel yang dihasilkan. Senyawa dengan rantai karbon terpendek akan terdeteksi lebih awal pada analisis GC-MS. Metil palmitat mempunyai rantai karbon paling pendek dibanding senyawa metil ester lainnya, sehingga muncul lebih awal dibandingkan metil linoleat, metil oleat, dan metil stearat. Puncak oleat muncul lebih dahulu dari metil stearat karena berat molekul metil stearat lebih besar dari pada berat molekul metil oleat. Asam lemak jenuh terpenting dalam komposisi biodiesel adalah asam palmitat, sedangkan asam lemak tak jenuh terpenting berupa asam oleat yang berisi satu ikatan rangkap. Asam lemak jenuh tinggi pada metil ester menjadi salah satu indikator biodiesel tahan terhadap oksidasi dari udara, dan mempunyai bilangan oktan yang tinggi (Firdaus dkk, 2013).

Waktu reaksi 120 menit menunjukkan adanya senyawa metil oktadeka 9,12 dienoat dan 180 menit menunjukkan adanya senyawa metil siklo propano-oktanoat yang tidak terdapat pada waktu reaksi lainnya dalam jumlah kecil. Hasil analisis sudah sesuai dengan penelitian Wahyuni, 2010 menyatakan bahwa penurunan nilai gliserol terikat menunjukkan bahwa jumlah mono, di, dan turunan trigliserida dalam jumlah kecil. Reaksi yang belum sempurna 
pada sintesis biodiesel dibuktikan dengan adanya puncak trigliserida dan metil ester hasil analisis GC-MS.

\section{KESI MPULAN}

Minyak ampas tahu yang diperoleh melalui ekstraksi pelarut benzene memiliki bilangan asam lemak bebas $0,6 \%$. Biodiesel dapat disintesis dari minyak ampas tahu melalui satu tahapan reaksi yaitu transeterifikasi melalui metode elektrokatalitik. Peningkatan waktu reaksi berpengaruh nyata terhadap yield biodiesel yang dihasilkan. Waktu reaksi 120 menit menghasilkan yield tertinggi sebesar 94\% dibanding waktu reaksi 60 menit sebesar $88 \%$, dan 180 menit sebesar $90 \%$. Kualitas biodiesel ditinjau dari densitas, viskositas, dan bilangan asam sudah memenuhi kualifikasi SNI Biodiesel 04-7182-2006. Hasil analisis GC-MS membuktikan bahwa produk yang dihasilkan memang biodiesel dengan komposisi jenis asam lemak utama: asam palmiat, asam oleat, asam linoleat, dan asam stearat.

\section{UCAPAN TERI MA KASI H}

Penulis menyampaikan terima kasih kepada pihak Akamigas Balongan Indramayu yang telah memberikan support dan segala fasilitas sehingga penelitian ini dapat terlaksana, Jurusan Kimia FMIPA UNJANI yang telah bersedia dalam peminjaman laboratorium, Laboratorium Analisis dan Instrumentasi UPI yang telah membantu dalam analisis GC-MS.

\section{DAFTAR RUJ UKAN}

British Standard International. The European Standard. Determination of FAME, mono-, di-, tri-glyceride for Oils and Fats. BSEN 14105:2003.

A, Irawati. (2018). Pembuatan dan Pengujian Viskositas dan Densitas Biodiesel dari Beberapa J enis Minyak Jelantah. JFT. 1(5), 82 - 89.

Allioux, F.-M., He, L., She, F., Hodgson, P. D., Kong, L., and Dumée, L. F. (2015). Investigation of hybrid ion-exchange membranes reinforced with non-woven metal meshes for electro-dialysis applications. Sep. Purif. Technol. 147, 353-363.

Anwaristiawan, D., Harjito, H., \& Widiarti, N. (2018). Modifikasi Katalis BaO/Zeolit Y pada Reaksi Transesterifikasi Minyak Biji Jarak (Jatropha Curcas L.) menjadi Biodiesel. Indonesian Journal of Chemical Science, 7(3), 292-298

Buchori, L. (2012). Pengambilan Minyak Kedelai dari Ampas Tahu Sebagai Bahan Baku Pembuat Biodiesel. Jurnal IImu Lingkungan, 10(2), 49-53.

Chen CL, Huang CC, Tran DT, \& Chang JS. (2012). Biodiesel synthesis via heterogeneous catalysis using modified strontium oxides as the catalysts. Bioresource Technol, 113, 8-13. 
Firdaus, L.H., Wicaksono, A.R. dan Widayat. (2013). Pembuatan Katalis Zeolit dengan Impregnasi KI/KIO3 dan Uji Kinerja Katalis untuk Produksi Biodiesel, J. Tek. Kim. dan Inds., 2(2), 148-154.

Fereidooni, L., Tahvildari, K., And Mehrpooya, M. 2017. Transesterification of Waste Cooking Oil with Methanol by Electrolisys Process Using KOH. Renew. Energy. 116, 183-193.

Kayser, H., Pienko, F., de Maria, P.D. (2014). Chitosan - Catalyzed Biodiesel Synthesis: Proofof-Concect and Limitations. Fuel. 116, 267-272.

Muhriz, M., Subagio, A. \& Pardoyo. (2011). Pembuatan Zeolit Nanopartikel dengan Metode High Energy Milling (Zeolite Nanoparticle Fabrication using High Energy Milling Method). Jurnal Sains dan Matematika, 19(1), 11-17.

Pahlevi, M.R., Anita, S. \& Nurhayati. (2015). Variasi Berat Katalis dan Suhu Reaksi Transesterifikasi Crude Palm Oil Menggunakan Katalis Cangkang Kerang Darah Kalsinasi $800^{\circ} \mathrm{C}$. Jom Fmipa. Volume 2(1), 186-191

Putra, R. S., Pratama, K., Antono, Y., Idris, M., Rua, J., and Ramadhani, H. (2016). Enhanced electrocatalytic biodiesel production with chitosan gel (hydrogel and xerogel). Proc. Eng. 148, 609-614.

R. S. K. Arita, Attaso, R. Septian. (2013). Pembuatan Biodiesel dari Minyak Sawit dengan Katalis CaO disinari dengan Gelombang Mikro. Jurnal Teknik Kimia, 19(4), 45-50.

Wisnu, I.M. \& Putra, A. (2017). Pembuatan dan Karakterisasi Katalis CaO/Zeolit Alam. Jurnal Media Sains, 1(1), 12-18

Dedy Irawan, et. all. (2019). Pengaruh Rasio Metanol dan KOH pada Proses Pembuatan Biodiesel dengan Metode Elektrolisis Menggunakan Elektroda Perak. Prosiding Senati, ISSN 208-4218 